\title{
PENGUJIAN EFEKTIVITAS HERBISIDA BERBAHAN AKTIF GLIFOSAT, MESOTRION, S-METOLAKLOR DAN CAMPURAN KETIGANYA TERHADAP GULMA TEKI
}

\author{
Ismawati, Nanik Sriyani \& Hidayat Pujisiswanto \\ Jurusan Agroteknologi Fakultas Pertanian Universitas Lampung \\ Jl. Prof. Dr. Soemantri Brodjonegoro No. 1, kodepos 35141 \\ Email : nsriyani06@yahoo.co.id
}

\begin{abstract}
ABSTRAK
Penelitian ini bertujuan untuk mengetahui pengaruh herbisida glifosat, mesotrion, s-metolaklor serta campuran ketiganya terhadap kerusakan gulma teki dan mengetahui apakah herbisida berbahan aktif campuran (glifosat+mesotrion+ + -metolaklor) bersifat aditif, antagonis atau sinergis dalam mengendalikan gulma teki. Penelitian disusun dalam Rancangan Petak Terbagi (Split Plot Design). Perlakuan terdiri dari glifosat dosis 1215, 2430, $4860 \mathrm{~g} / \mathrm{ha}$, mesotrion dosis 24, 48, $96 \mathrm{~g} / \mathrm{ha}$, s-metolaklor dosis 249,6, 499,2, 998,4 g/ha, dan glifosat+mesotrion+s-metolaklor dosis 525, 1050, $2100 \mathrm{~g} / \mathrm{ha}$. Gulma sasaran merupakan gulma teki (Cyperus kyllingia, Cyperus rotundus, dan Cyperus compressus). Analisis data dilakukan menggunakan metode Multiplicative Survival Model (MSM). Data bobot kering yang diperoleh dikonversi menjadi persen kerusakan. Data persen kerusakan ditransformasi kedalam bentuk logaritmik untuk mendapat nilai persamaan regesi linear. Persamaan regresi digunakan untuk menentukan nilai $\mathrm{LD}_{50}$ perlakuan dan $\mathrm{LD}_{50}$ harapan dan nilai ko-toksisitas. Hasil penelitian menunjukkan bahwa herbisida glifosat pada dosis 1215, 2430, $4860 \mathrm{~g}$ /ha menyebabkan kerusakan gulma, menurunkan bobot kering, dan menyebabkan gejala klorosis. Herbisida mesotrion pada dosis 24, 48, $96 \mathrm{~g}$ /ha menyebabkan kerusakan gulma dan menyebabkan gejala bleaching. Herbisida s-metolaklor pada dosis 249,6, 499,2, 998,4 g/ha tidak menyebabkan kerusakan gulma. Herbisida berbahan aktif campuran (glifosat+mesotrion+s-metolaklor) pada dosis 525, 1050, $2100 \mathrm{~g}$ /ha menyebabkan kerusakan pada gulma Cyperus rotundus dan Cyperus compressus. Gulma yang diaplikasi herbisida glifosat memiliki nilai kehijauan daun, jumlah stomata, dan bobot kering terendah pada seluruh taraf dosis aplikasi. Herbisida berbahan aktif campuran (glifosat+mesotrion+smetolaklor) memiliki nilai $\mathrm{LD}_{50}$ harapan $55,8 \mathrm{~g} / \mathrm{ha}$ dan $\mathrm{LD}_{50}$ perlakuan sebesar 139,67 $\mathrm{g} /$ ha dengan nilai ko-toksisitas sebesar 0,39 (ko-toksisitas $<1$ ) sehingga campuran bersifat antagonis.
\end{abstract}

Kata Kunci : glifosat, $\mathrm{LD}_{50}$, mesotrion, MultiplicativeSurvival Model (MSM),s-metolaklor.

\section{PENDAHULUAN}

Herbisida merupakan pestisida (senyawa kimia organik maupun anorganik) yang digunakan untuk mengendalikan pertumbuhan gulma karena dapat menghambat atau mematikan pertumbuhan gulma (Tu dkk., 2001). Herbisida berbahan aktif campuran sedang pesat dikembangkan dan dipasarkan. Salah satu jenis kombinasi bahan aktif herbisida adalah herbisida berbahan aktif glifosat, mesotrion dan s-metolaklor.

Glifosat bersifat sistemik non-selektif. Mekanisme kerja glifosat menghambat biosintesis asam amino aromatik (Varshney dan Shondia, 2004). Mesotrion bersifat sistemik dan selektif. Mekanisme kerja mesotrion menghambat pembentukan dioksigenase 4-hydroxyphenylpyruvate (HPPD) (Mitchell dkk, 2001).S-metolaklor bersifat sistemik dan selektif. Mekanisme kerja s-metolaklor menghambat klorofil dan sintesis protein pada tumbuhan (Lowry dkk.,
2013). Disisi lain, pencampuran lebih dari 1 bahan aktif dapat bersifat aditif, sinergis, dan antagonis dengan bahan aktif lainya. Oleh karena itu, perlu pengkajian mengenai kombinasi bahan aktif herbisida yang akan digunakan. Pengujian kombinasi bahan aktif dengan cara kerja berbeda dapat dilakukan dengan metode analisis MSM (Multiplicative Survival Model ) (Streibig, 2003).

Tujuan penelitian ini adalah mengetahui pengaruh herbisida tunggal glifosat, mesotrion, smetolaklor dan herbisida campuran ketiganya terhadap kerusakan gulma teki dan mengetahui apakah herbisida campuran glifosat + mesotrion $+\mathrm{s}$-metolaklor bersifat aditif, antagonis atau sinergis dalam mengendalikan gulma teki.

\section{BAHAN DAN METODE}

Penelitian dilakukan di Rumah Kaca dan Laboratorium Ilmu Gulma Fakultas Pertanian 
Universitas Lampung. Waktu penelitian berlangsung dari Januari 2016 sampai Maret 2016.

Bahan-bahan yang akan digunakan dalam penelitian ini adalah herbisida berbahan aktif campuran glifosat $250 \mathrm{~g} / \mathrm{ha}+$ mesotrion $25 \mathrm{~g} / \mathrm{ha}+\mathrm{s}$-metolaklor 250 $\mathrm{g} /$ ha (Halex $525 \mathrm{ZC}$ ), Herbisida berbahan aktif tunggal glifosat (Round-Up 486 SL), mesotrion (Callisto 480 SC), s-metolaklor (Dual Gold 960 EC), gulma Cyperus compressus, Cyperus kyllingia, Cyperus rotundus, kantong kertas, label, cat kuku bening, serta pot dengan kapasitas volume $1 / 2 \mathrm{~kg}$ tanah. Alat-alat yang digunakan adalah knapsack sprayer dengan nosel berwarna biru, gelas ukur, gelas piala, selotip transparan,pinset, oven, gunting, ruber bulb, mikroskop, timbangan, gelas air meineral, ember, cangkul, koret, karung, dan SPAD (Soil Plant Analysis Develpment ) 502.

Penelitian ini disusun dalam Rancangan Petak Terbagi (Split Plot Design) terdiri dari 2 faktor dengan 6 ulangan. Petak utama adalah jenis gulma: $\mathrm{Cc}=($ Cyperus compressus $), \mathrm{Ck}=($ Cyperus kyllingia $)$, dan $\mathrm{Cr}=($ Cyperus rotundus $)$. Anak petak adalah dosis perlakuan herbisida berbahan aktif tunggal dan campuran.Perlakuan terdiri dari glifosat dosis 1215, 2430, $4860 \mathrm{~g} / \mathrm{ha}$, mesotrion dosis 24, 48, $96 \mathrm{~g} / \mathrm{ha}$, s-metolaklor dosis 249,6, 499,2, 998,4 g/ha, dan glifosat+mesotrion+smetolaklor dosis 525, 1050, $2100 \mathrm{~g} / \mathrm{ha}$. Jumlah unit penelitian adalah 234 satuan percobaan.

Data hasil pengamatan dianalisis dengan menggunakan uji homogenitas untuk menguji homogenitas ragam, pengujian aditivitas diuji menggunakan uji Tukey. Jika asumsi terpenuhi, data dianalisis dengan sidik ragam dan dilakukan pengujian nilai tengah perlakuan dengan uji BNT (Beda Nyata Terkecil) pada taraf 5\%.

Pengamatan yang dilakukan meliputi gejala keracunan; kehijauan daun; anatomi dan jumlah stomata daun; dan bobot kering gulma. Gejala keracunan gulma diamati pada 1 MSA dan 2 MSA. Kehijauan daun diamati pada 1 dan 2 MSA. Pengamatan dilakukan menggunakan klorofil meter SPAD 502.Anatomi dan jumlah stomata daun diamati pada 2 MSA. Anatomi dan jumlah stomata diamati satu helai daun pada setiap perlakuan. Metode pengamatan menggunakan cat kuku bening yang dioleskan pada daun bagian abaksial (bawah) selama 5-10 menit. Setelah cat kering, cetakan diangkat dengan selotip transparan kemudian diletakkan di atas gelas preparat lalu diamati menggunakan mikroskop bagaimana anatomi stomata daun gulma dengan perbesaran 40x dan 100x.Penetapan bobot kering gulma dilakukan dengan mengoven bagian gulma segar yang telah dipanen pada $2 \mathrm{MSA}$ dengan suhu $80^{\circ} \mathrm{C}$ selama 48 jam hingga tercapai bobot kering konstan.
Analisis data. Data gejala keracunan dan anatomi stomata yang telah dipoto dilihat bagaiman kerusakanya. Analisis datadilakukan dengan cara data kehijauan daun dan data bobot kering dianalisis menggunakan BNT 5 $\%$. Data bobot kering gulma dikonversi menjadi persen kerusakan. Persen kerusakan gulma dapat dihitung dengan rumus sebagai berikut:\%KP $=(1-\mathrm{Bsp} / \mathrm{Bsk}) \mathrm{x}$ $100 \%$

$\% \mathrm{KP}=$ Persen kerusakan perlakuan.

Bsp = Bobot kering bagian gulma segar herbisida .

Bsk = Bobot kering bagian gulma kontrol.

Persen kerusakan yang diperoleh kemudian dikonversi kedalam nilai probit. Nilai probit dapat dicari menggunakan rumus NORMINV, kemudian dosis diubah kedalam bentuk log dosis menggunakan rumus LOG pada Microsof Excel. Dari nilai probit (Y) dan $\log$ dosis (X) akan diperoleh regresi linear.

\section{Nilai $L D_{50}$ Perlakuan}

Nilai $\mathrm{LD}_{50}$ Perlakuan diperoleh dengan cara:

a. Menghitung nilai probit masing-masing herbisida (Ismawati, 2016).

b. Menghitung $\mathrm{LD}_{50}$ perlakuan masing-masing herbisida (Ismawati, 2016).

c. Menghitung nilai $\mathrm{LD}_{50}$ perlakuan masing-masing herbisida dalam $\mathrm{LD}_{50}$ perlakuan campuran herbisida (Ismawati, 2016).

d. Menghitung persen kerusakan masing-masing herbisida (Ismawati, 2016).

e. Menghitung persen kerusakan campuran herbisida pada $\mathrm{LD}_{50}$ perlakuan

$\mathrm{P}_{(\mathrm{A}+\mathrm{B}+\mathrm{C})}=\mathrm{P}_{(\mathrm{A})}+\mathrm{P}_{(\mathrm{B})}+\mathrm{P}_{(\mathrm{C})}-\mathrm{P}_{(\mathrm{A})} \mathrm{xP}_{(\mathrm{B})} \times \mathrm{P}_{(\mathrm{C})}$ Keterangan:

$\mathrm{P}_{(\mathrm{A})} \quad=$ Persen kerusakan oleh herbisida $\mathrm{A}$

$\mathrm{P}_{(\mathrm{B})} \quad=$ Persen kerusakan oleh herbisida $\mathrm{B}$

$\mathrm{P}_{(\mathrm{C})} \quad=$ Persen kerusakan oleh herbisida $\mathrm{C}$

$\mathrm{P}_{(\mathrm{A}+\mathrm{B}+\mathrm{C})}=$ Persen kerusakan perlakuan herbisida campuran.

\section{Nilai $L D_{50}$ Harapan}

Nilai $\mathrm{LD}_{50}$ Harapan diperoleh dengan cara:

a. Mengubah $\mathrm{LD}_{50}$ perlakuan masing-masing komponen herbisida (X1, X2,dan X3) (Ismawati, 2017).

b. Mengubah nilai probit Y1, Y2, dan Y3(Ismawati, 2017).

c. Dilihat nilai yang mendekati nilai Y1, Y2 dan Y3 yang telah diperoleh dari hasil sebelumnya pada tabel probit (Ismawati, 2017).

d. Diubah nilai Y1, Y2, dan Y3 menjadi persen kerusakan dengan mengubah nilai Y1, Y2, dan Y3 menjadi anti probit pada tabel probit (Ismawati, 2017). 
e. Menghitung persen kerusakan campuran herbisida pada $\mathrm{LD}_{50}$ harapan dengan menggunakan rumus:

$$
\mathrm{P}_{(\mathrm{A}+\mathrm{B}+\mathrm{C})}=\mathrm{P}_{(\mathrm{A})}+\mathrm{P}_{(\mathrm{B})}+\mathrm{P}_{(\mathrm{C})}-\mathrm{P}_{(\mathrm{A})} \times \mathrm{P}_{(\mathrm{B})} \times \mathrm{P}_{(\mathrm{C})}
$$

f. Menentukan $\mathrm{LD}_{50}$ harapan (Ismawati, 2017).

g. Dilihat dosis herbisida setelah mengalami perubahan nilai $\mathrm{X} 1, \mathrm{X} 2$ dan $\mathrm{X} 3$ yang menyebabkan persen kerusakan harapan herbisida campuran mendekati $50 \%$. Kemudian, dilakukan penjumlahan dosis $\mathrm{X} 1$, X2, dan X3 tersebut (Ismawati, 2017).

Nilai ko-toksisitas $\mathrm{LD}_{50}$ diperoleh dengan caranilai ko-toksisitas $=\mathrm{LD}_{50}$ harapan dibagi dengan $\mathrm{LD}_{50}$ perlakuan. Nilai ko-toksisistas $>1$ berati campuran herbisida tersebut sinergis, namun jika nilai $<1$ berati campuran tersebut antagonis (Streibig, 2003).

\section{HASIL DAN PEMBAHASAN}

Pembahasan hasil penelitian berupa gejala keracunan, kehijauan daun, anatomi stomata daun gulma, bobot kering gulma, dan sifat pencampuran herbisida glifosat+mesotrion + s-metolaklor terhadap gulma teki menggunakan metode MSM (Multiplicative Survival Model). Hasil data pengamatan dijelaskan sebagai berikut:

Gejala keracunan. Gejala keracunan berupa kuning kecoklatan pada gulma yang diaplikasi herbisida berbahan aktif glifosat+mesotrion+s-metolaklor. Gejala keracunan yang paling dominan adalah gejala klorosis. Gejala tersebut ditimbulkan oleh herbisida glifosat (Purba,1996). Gejala yang dihasilkan akibat aplikasi glifosat adalah nekrosis dan klorosis (Purba, 1996). Gejala keracunan lain yang timbul adalah gejala pemutihan atau bleaching. Gejala keracunan tersebut diakibatkan oleh herbisida mesotrion. Herbisida berbahan aktif mesotrion merupakan inhibitor dioksigenase 4-hydroxyphenylpyruvate (HPPD) yang mencegah terbentuknya karotenoid sehingga terjadi degradasi klorofil dan menimbulkan gejala pemutihan pada tumbuhan (Harms dalam Hausman, 2011). Pada percobaan yang telah dilakukan, aplikasi herbisida smetolaklor tidak menimbulkan gejala keracunan disebabkan karena herbisida metolaklor merupakan herbisida yang diaplikasikan ke tanah (Vencill dkk, dalam Baidhawi 2014).

Kehijaun Daun. Nilai kehijauan daun gulma $C$. kyllingia berbeda nyata dengan gulma $C$. rotundus dan C. compressus. Perbedaan terbesar terdapat pada glifosat 1215, 2430 dan $4860 \mathrm{~g} /$ ha (Tabel 1) memiliki nilai kehijauan terendah hal tersebut dikarenakan daun gulma berubah warna menjadi coklat dan mengering. Nilai tersebut sangat berbeda nyata jika dibandingkan dengan dosis aplikasi $0 \mathrm{~g} / \mathrm{ha}$.

Anatomi dan Jumlah Stomata Daun. Seluruh jenis gulma yang memiliki jumlah stomata terendah dan mengalami kerusakan stomata dan lekukan epidermis yang parah adalah gulma yang diaplikasi herbisida glifosat 2430 dan $4860 \mathrm{~g} / \mathrm{ha}$ (Gambar 1). Pada seluruh gulma yang diaplikasi s-metolaklor tidak mengalami kerusakan stomata dan lekukan epidermis. Gulma $C$. compressus yang diaplikasi glifosat memiliki jumlah stomata terendah. Gulma C. rotundus yang diaplikasi s-metolaklor memiliki jumlah stomata tertinggi namun tidak lebih tinggi dari kontrol (Tabel 2).

Bobot Kering Gulma. Glifosat 2430 dan 4860 g/ ha memiliki nilai bobot kering gulma terendah. Hal tersebut dikarenakan gulma mengalami kematian. Nilai tersebut sangat berbeda nyata jika dibandingkan dengan dosis aplikasi $0 \mathrm{~g} / \mathrm{ha}$. Nilai bobot kering berfungsi untuk mengetahui persentase kerusakan gulma kemudian dihitung nilai probitnya. Nilai probit digunakan untuk menganalisis sifat pencampuran herbisida (Tabel 3).

Analisis Campuran Herbisida. Nilai $\mathrm{LD}_{50}$ perlakuan menunjukkan bahwa terdapat dosis tertentu dari perlakuan herbisida yang dapat mengendalikan/ merusak gulma Cyperus kyllingia, Cyperus rotundus,

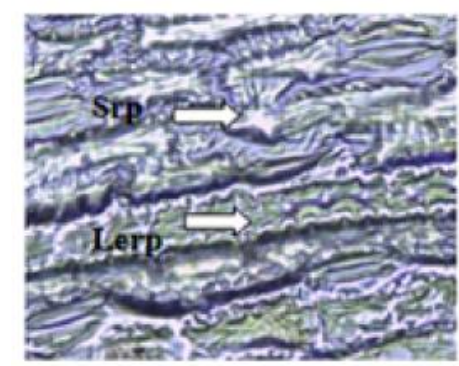

(a)

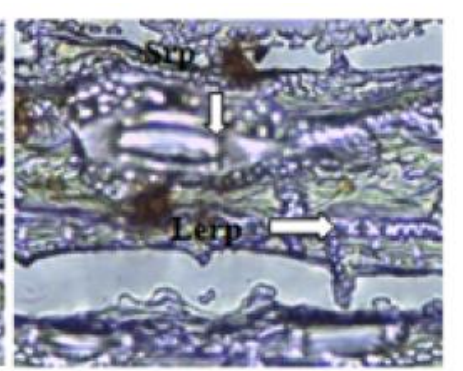

(b)

Gambar 1. Anatomi Stomata Daun Gulma. (a) Glifosat $2430 \mathrm{~g} /$ ha (b) Glifosat $4860 \mathrm{~g} / \mathrm{ha}$. srp=stomata rusak parah; lerp=lekukan epidermis rusak parah. 
Tabel 1. Kehijauan daun 2 MSA

\begin{tabular}{llccc}
\hline No & \multicolumn{1}{c}{ Gulma } & Dosis Bahan Aktif (g/ha) & Kehijauan & \\
\hline 1. & Cyperus kyllingia & - & 22,38 & $\mathrm{~A}$ \\
2. & Cyperus rotundus & - & 15,50 & $\mathrm{~B}$ \\
3. & Cyperus compressus & - & 11,55 & $\mathrm{~B}$ \\
\hline & BNT 5\% & & 4,66 & \\
\hline & \multicolumn{1}{c}{ Herbisida } & & Kehijauan & \\
\hline 1. & (glifosat+mesotrion+s-metolaklor) & 525 & 15,0 & $\mathrm{de}$ \\
2. & (glifosat+mesotrion+s-metolaklor) & 1050 & 15,3 & $\mathrm{de}$ \\
3. & (glifosat+mesotrion+s-metolaklor) & 2100 & 14,0 & $\mathrm{de}$ \\
4. & Glifosat & 1215 & 4,9 & $\mathrm{f}$ \\
5. & Glifosat & 2430 & 2,5 & $\mathrm{f}$ \\
6. & Glifosat & 4860 & 0,4 & $\mathrm{f}$ \\
7. & Mesotrion & 24 & 17,4 & $\mathrm{cde}$ \\
8. & Mesotrion & 48 & 17,4 & $\mathrm{cde}$ \\
9. & Mesotrion & 96 & 19,4 & $\mathrm{bcd}$ \\
10. & S-metolaklor & 249,6 & 24,0 & $\mathrm{~b}$ \\
11. & S-metolaklor & 499,2 & 23,9 & $\mathrm{~b}$ \\
12. & S-metolaklor & 998,4 & 21,6 & $\mathrm{bc}$ \\
13. & Kontrol & 0 & 38,4 & $\mathrm{a}$ \\
\hline & BNT 5\% & & 6,46 & \\
\hline
\end{tabular}

dan Cyperus compressus sebanyak 50\%. Tabel 4 menunjukkan bahwa di lapangan diperlukan glifosat 459,62 g/ha, mesotrion 69,69 g/ha, s-metolaklor 1334,136 $\mathrm{g} /$ ha, dan herbisida campuran (glifosat + mesotrion $+\mathrm{s}-$ metolaklor) $139,67 \mathrm{~g} / \mathrm{ha}$. Nilai dosis tersebut merupakan gabungan dosis dari masing-masing komponen bahan aktif, dengan rasio komponen glifosat : mesotrion : smetolaklor sebesar $10: 1: 10$.

Model MSM (Multiplicative Survival Model). Metode MSM digunakan untuk mengetahui sifat pencampuran herbisida yang memiliki cara kerja berbeda. Setelah nilai dosis perlakuan diketahui, nilai dosis $\mathrm{LD}_{50}$ yang sebenarnya dari campuran herbisida dinyatakan dalam $\mathrm{LD}_{50}$ harapan. Nilai dosis komponen campuran dimasukkan kedalam persamaan regresi linier probit dari masing-masing herbisida tunggal dalam bentuk logaritmik, sehingga dengan mengacu pada tabel probit dapat diketahui nilai persen kerusakan gulma yang disebabkan oleh herbisida glifosat, mesotrion, dan smetolaklor. \%kerusakan akibat glifosat $=0,02 \%(\mathrm{PA})$; akibat mesotrion $=35,3 \%(\mathrm{~PB})$; akibat s-metolaklor $=$ $27,6 \%(\mathrm{PC})$; dan akibat herbisida campuran $=62,90 \%$.

Nilai tersebut lebih dari 50\%, sehingga dengan mengurangi dosis (mengubah nilai X1, X2, dan X3) diperoleh dosis dari masing-masing herbisida campuran sebesar: glifosat $(X 1)=26,6$; Mesotrion $(X 2)=2,6$; SMetolaklor $(X 3)=26,6$. Dosis tersebut maka kerusakan gulma oleh masing-masing komponen campuran (nilai probit) adalah sebesar: glifosat $(\mathrm{Y} 1)=1,0098$; Mesotrion $(\mathrm{Y} 2)=4,4756$; S-Metolaklor $(\mathrm{Y} 3)=4,2244$.

Setelah dikonversi dalam bentuk anti-probit, maka kerusakan gulma oleh masing-masing komponen herbisida adalah sebesar: glifosat $(\mathrm{Y} 1)=0,01 \%(\mathrm{PA})$; Mesotrion $(\mathrm{Y} 2)=30,0 \%(\mathrm{~PB})$; S-Metolaklor $(\mathrm{Y} 3)=$ $21,9 \%$ (PC). Tingkat kerusakan gulma 50\% (harapan) diketahui berdasarkan persamaan probit:

$\mathrm{P}(\mathrm{ABC})$

$=\mathrm{PA}+\mathrm{PB}+\mathrm{PC}-$ PA.PB.PC

$=0,01+30+21,9-0,01=51,90 \%$

sehingga:

$\mathrm{LD}_{50}$ harapan $=26,6+2,6+26,6=55,8 \mathrm{~g} / \mathrm{ha}$

$\mathrm{LD}_{50}$ perlakuan $=66,5+6,65+66,5=139,67 \mathrm{~g} / \mathrm{ha}$

Ko-toksisitas

$=\mathrm{LD}_{50}$ harapan $/ \mathrm{LD}_{50}$ perlakuan

$=55,8 / 139,67$

$=0,39$ 
Tabel 2. Jumlah Stomata Daun

\begin{tabular}{|c|c|c|c|c|}
\hline \multirow[t]{2}{*}{ Gulma } & \multicolumn{3}{|c|}{ Herbisida } & \multirow[b]{2}{*}{$\begin{array}{l}\text { Jumlah } \\
\text { stomata }\end{array}$} \\
\hline & Bahan aktif & Dosis Bahan aktif (g/ha) & $\begin{array}{l}\text { Stomata dan } \\
\text { lekukan epidermis }\end{array}$ & \\
\hline \multirow{13}{*}{$\begin{array}{l}\text { Cyperus } \\
\text { Kyllingia }\end{array}$} & Glifosat + mesotrion $+\mathrm{s}-$ & 525 & Rusak & 96 \\
\hline & metolaklor & 1050 & Rusak & 98 \\
\hline & & 2100 & Rusak & 103 \\
\hline & & 1215 & Rusak & 66 \\
\hline & Glifosat & 2430 & Rusak parah & 0 \\
\hline & & 4860 & Rusak parah & 0 \\
\hline & & 24 & Rusak & 112 \\
\hline & Mesotrion & 48 & Rusak & 90 \\
\hline & & 96 & Rusak & 101 \\
\hline & & 249,6 & Normal & 112 \\
\hline & S-metolaklor & 499,2 & Normal & 85 \\
\hline & & 998,4 & Normal & 111 \\
\hline & Kontrol & 0 & Normal & 116 \\
\hline \multirow{13}{*}{$\begin{array}{l}\text { Cyperus } \\
\text { Rotundus }\end{array}$} & Glifosat + mesotrion $+\mathrm{s}-$ & 525 & Rusak & 111 \\
\hline & metolaklor & 1050 & Rusak & 98 \\
\hline & & 2100 & Rusak & 88 \\
\hline & & 1215 & Rusak & 82 \\
\hline & Glifosat & 2430 & Rusak parah & 0 \\
\hline & & 4860 & Rusak parah & 0 \\
\hline & & 24 & Rusak & 73 \\
\hline & Mesotrion & 48 & Rusak & 172 \\
\hline & & 96 & Rusak & 96 \\
\hline & & 249,6 & Normal & 300 \\
\hline & S-metolaklor & 499,2 & Normal & 190 \\
\hline & & 998,4 & Normal & 167 \\
\hline & Kontrol & 0 & Normal & 360 \\
\hline \multirow{13}{*}{$\begin{array}{l}\text { Cyperus } \\
\text { Compresus }\end{array}$} & Glifosat + mesotrion $+\mathrm{s}-$ & 525 & Rusak & 48 \\
\hline & metolaklor & 1050 & Rusak & 150 \\
\hline & & 2100 & Rusak & 33 \\
\hline & & 1215 & Rusak & 61 \\
\hline & Glifosat & 2430 & Rusak parah & 0 \\
\hline & & 4860 & Rusak parah & 0 \\
\hline & & 24 & Rusak & 48 \\
\hline & Mesotrion & 48 & Rusak & 71 \\
\hline & & 96 & Rusak & 136 \\
\hline & & 249,6 & Normal & 44 \\
\hline & S-metolaklor & 499,2 & Normal & 46 \\
\hline & & 998,4 & Normal & 126 \\
\hline & Kontrol & 0 & Normal & 160 \\
\hline
\end{tabular}


Tabel 3. Bobot Kering Gulma

\begin{tabular}{|c|c|c|c|c|c|}
\hline No & Herbisida & $\begin{array}{l}\text { Dosis Bahan } \\
\text { Aktif (g/ha) }\end{array}$ & C. kyllingia & C. rotundus & C. compressus \\
\hline 1. & $\begin{array}{l}\text { Glifosat }+ \text { mesotrion }+s- \\
\text { metolaklor }\end{array}$ & 525 & $\begin{array}{l}0,30 \mathrm{bcd} \\
\text { A }\end{array}$ & $\begin{array}{l}0,30 \mathrm{de} \\
\text { A }\end{array}$ & $\begin{array}{l}0,20 \mathrm{ef} \\
\mathrm{A}\end{array}$ \\
\hline 2. & $\begin{array}{l}\text { Glifosat }+ \text { mes otrion }+s- \\
\text { metolaklor }\end{array}$ & 1050 & $\begin{array}{l}0,23 \mathrm{de} \\
\text { A }\end{array}$ & $\begin{array}{l}0,22 \mathrm{ef} \\
\mathrm{A}\end{array}$ & $\begin{array}{l}0,15 f g \\
\text { A }\end{array}$ \\
\hline 3. & $\begin{array}{l}\text { Glifosat }+ \text { mes otrion }+s- \\
\text { metolaklor }\end{array}$ & 2100 & $\begin{array}{l}0,24 \mathrm{cde} \\
\text { B }\end{array}$ & $\begin{array}{l}0,15 f \\
B\end{array}$ & $\begin{array}{l}0,72 \mathrm{~b} \\
\mathrm{~A}\end{array}$ \\
\hline 4. & Glifosat & 1215 & $\begin{array}{l}0,13 \mathrm{ef} \\
\mathrm{A}\end{array}$ & $\begin{array}{l}0,00 \mathrm{~g} \\
\mathrm{~A}\end{array}$ & $\begin{array}{l}0,02 \mathrm{gh} \\
\mathrm{A}\end{array}$ \\
\hline 5. & Glifosat & 2430 & $\begin{array}{l}0,02 \mathrm{f} \\
\mathrm{A}\end{array}$ & $\begin{array}{l}0,00 \mathrm{~g} \\
\mathrm{~A}\end{array}$ & $\begin{array}{l}0,00 \mathrm{~h} \\
\mathrm{~A}\end{array}$ \\
\hline 6. & Glifos at & 4860 & $\begin{array}{l}0,00 \mathrm{f} \\
\mathrm{A}\end{array}$ & $\begin{array}{l}0,00 \mathrm{~g} \\
\mathrm{~A}\end{array}$ & $\begin{array}{l}0,00 \mathrm{~h} \\
\mathrm{~A}\end{array}$ \\
\hline 7. & Mesotrion & 24 & $\begin{array}{l}0,39 b \\
A\end{array}$ & $\begin{array}{l}0,39 \mathrm{bcd} \\
\text { A }\end{array}$ & $\begin{array}{l}0,28 \mathrm{ef} \\
\text { A }\end{array}$ \\
\hline 8. & Mes otrion & 48 & $\begin{array}{l}0,40 \mathrm{~b} \\
\mathrm{~A}\end{array}$ & $\begin{array}{l}0,46 \mathrm{bc} \\
\text { A }\end{array}$ & $\begin{array}{l}0,18 \mathrm{ef} \\
B\end{array}$ \\
\hline 9. & Mesotrion & 96 & $\begin{array}{l}0,36 \mathrm{bc} \\
\mathrm{AB}\end{array}$ & $\begin{array}{l}0,37 \mathrm{bcd} \\
\text { A }\end{array}$ & $\begin{array}{l}0,18 \mathrm{ef} \\
\mathrm{C}\end{array}$ \\
\hline 10. & S-metolaklor & 249,6 & $\begin{array}{l}0,33 \mathrm{bcd} \\
\text { B }\end{array}$ & $\begin{array}{l}0,49 \mathrm{~b} \\
\mathrm{~A}\end{array}$ & $\begin{array}{l}0,44 \mathrm{~cd} \\
\text { A }\end{array}$ \\
\hline 11. & S-metolaklor & 499,2 & $\begin{array}{l}0,36 \mathrm{bc} \\
\text { A }\end{array}$ & $\begin{array}{l}0,37 \mathrm{bcd} \\
\text { A }\end{array}$ & $\begin{array}{l}0,46 \mathrm{c} \\
\mathrm{A}\end{array}$ \\
\hline 12. & S-metolaklor & 998,4 & $\begin{array}{l}0,36 \mathrm{bc} \\
\text { A }\end{array}$ & $\begin{array}{l}0,35 \mathrm{cde} \\
\mathrm{A}\end{array}$ & $\begin{array}{l}0,31 \mathrm{de} \\
\text { A }\end{array}$ \\
\hline 13. & Kontrol & 0 & $\begin{array}{l}0,64 \mathrm{a} \\
\mathrm{A}\end{array}$ & $\begin{array}{l}0,72 \mathrm{a} \\
\mathrm{A}\end{array}$ & $\begin{array}{l}0,75 \mathrm{a} \\
\mathrm{A}\end{array}$ \\
\hline
\end{tabular}

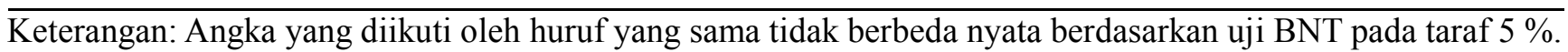

Tabel 4. Persamaan regresi probit dan nilai $\mathrm{LD}_{50}$ perlakuan

\begin{tabular}{lcccc}
\hline Herbisida & Persamaan Garis & Nilai R2 (\%) & LD $_{50}$ Perlakuan (g/ha) \\
\cline { 1 - 2 } Glifosat+Mesotrion+S-metolaklor & $\mathrm{Y}=0,489 \mathrm{X}+3,9851$ & 85,9 & 139,67 \\
Glifosat & $\mathrm{Y}=3,804 \mathrm{X}-5,128$ & 93,1 & 459,62 \\
Mesotrion & $\mathrm{Y}=0,370 \mathrm{X}+4,318$ & 97,6 & 69,69 \\
S-metolaklor & $\mathrm{Y}=0,455 \mathrm{X}+3,578$ & 84 & 1334,13 \\
\hline
\end{tabular}

Keterangan: $\mathrm{Y}=$ Nilai Probit dari rata-rata persen kerusakan 3 jenis gulma, $\mathrm{X}=\log$ Dosis 
Berdasarkan hasil perhitungan dengan model MSM diatas, maka nilai $\mathrm{LD}_{50}$ perlakuan lebih besar dari $\mathrm{LD}_{50}$ harapan, nilai ko-toksisitas $=0,39$ atau kurang dari $1(<1)$ sehingga campuran bersifat antagonis.

\section{KESIMPULAN}

Herbisida glifosat pada dosis $1215,2430,4860 \mathrm{~g} /$ ha menyebabkan kerusakan gulma, menurunkan bobot kering, dan menyebabkan gejala klorosis. Herbisida mesotrion pada dosis $24,48,96 \mathrm{~g} /$ ha menyebabkan kerusakan gulma dan menyebabkan gejala bleaching. Herbisida s-metolaklor pada dosis 249,6, 499,2, 998,4 g/ ha tidak menyebabkan kerusakan gulma. Herbisida berbahan aktif campuran (glifosat + mesotrion + smetolaklor) pada dosis 525, 1050, $2100 \mathrm{~g} / \mathrm{ha}$ menyebabkan kerusakan pada gulma Cyperus rotundus dan Cyperus compressus. Gulma yang diaplikasi herbisida glifosat memiliki nilai kehijauan daun, jumlah stomata, dan bobot kering terendah pada seluruh taraf dosis aplikasi. Herbisida berbahan aktif campuran (glifosat + mesotrion + s-metolaklor) memiliki nilai LD50 harapan 55,8 g/ha dan LD50 perlakuan sebesar 139,67 $\mathrm{g} / \mathrm{ha}$ dengan nilai ko-toksisitas sebesar 0,39 (kotoksisitas $<1$ ) sehingga campuran bersifat antagonis.

\section{DAFTAR PUSTAKA}

Akin, H. M. 2006. Virologi Tumbuhan. Kanisius. Yogyakarta.

Auld, B. A. dan K.U. Kim 1996. Weed Management in Rice. FAO Plant Protection and Protection Paper. Itali.
Baidhawi. 2014. Persistensi Herbisida Metolachlor Pada Tanah yang Berbeda Kandungan Bahan Organik. Jurnal Budidaya Pertanian. 10 (1) : 59 - 65.

Ismawati. 2017. Pengujian Efektivitas Herbisida Berbahan Aktif Glifosat, Mesotrion, S. Metolaklor dan Campuran Ketiganya Terhadap Gulma Teki. Skripsi. Universitas Lampung.

Lowry, D.M., D. Greiner., M. Fretheim., M. Ubben., dan K. R. Dhanwada. 2013. Mechanism of Metolachlor Action Due to Alterations In Cell Cycle Progression. Journal Cell Biol Toxicol 29 (4) : $91-283$.

Mitchell, G., D.W. Bartlett., T. E. Fraser., T. R. Hawkes., D.C. Holts., J. K. Townson., dan R. Wichert. 2001. Mesotrione: A New Selective Herbicide forUse In Maize. Journal Pest Management. $57(2): 8-120$.

Moody, Keith. 1989. Weeds Reported in Rice in South and Southeast Asia. International Rice Research Institite. Philippines

Purba, E. dan S. J. Damanik. 1996. Dasar-Dasar Ilmu Gulma. USU Press. Medan.

Streibig, J. C. 2003. Assessment of herbicide effects. CRC Press, Boca Raton, Florida. USA.

Tu, M. C., Hurd dan J. M. Randall. 2001. Weed Control Methods Handbook: Tools and Techniques for Use in Natural Areas. WildlandInvasive Species Team. USA.

Varshney, J. G. dan S.Shondhia. 2004. Weed Management. National Research Weed Centre for Science. India. 